\title{
Correlation of c-erbB-2, EGF and EGFR expression with postoperative survival of patients with advanced carcinoma of the stomach.
}

\author{
Jolanta Czyzewska1, Katarzyna Guzinska-Ustymowicz², Andrzej Kemona² \\ ${ }^{1}$ Department of Clinical Laboratory Diagnostics, ${ }^{2}$ Department of General Pathomorphology, \\ Medical University of Bialystok, Bialystok, Poland.
}

\begin{abstract}
The c-erbB-2 (HER-2/neu), EGF and EGFR (erbB-1) proteins, members of the epidermal growth factor receptor family, play a role in cell growth by binding to cell membrane receptors. The aim of the current study was to evaluate the expression of c-erbB-2, EGF and EGFR in advanced gastric carcinoma and to analyze its relationship with chosen anatomo-clinical parameters and prognosis. Standard avidin-biotin-peroxidase was used for c-erbB-2, EGF and EGFR immunohistochemical staining (Novostain Super ABC Kit Universal); anti-human c-erbB-2 protein monoclonal antibody NCL-cerbB-2-316, anti-Epidermal Growth Factor monoclonal antibody (clone EGF-10) and EGFR goat polyclonal IgG (pEGFR). A statistically significant correlation was found between c-erbB-2, EGF, EGRF expressions in the main mass of tumor and lymph node metastasis $(p=0.000 ; p=0.000 ; p=0.00001$, respectively). Also an association was observed between c-erbB-2 expression and Bormann's and Lauren's classifications ( $p=0.05 ; p=0.006$, respectively). Similarly, the expression of EGFR in main mass of tumor was correlated with the depth of invasion $(\mathrm{p}=0.007)$ and histological differentiation $(p=0.04)$. Moreover, the expression of c-erbB-2 in the main mass of tumor and lymph node metastasis was associated with the age of the patients $(p=0.03 ; p=0.0002$ respectively). Strong association was found between the expression of EGRF in lymph node metastasis and histological differentiation $(\mathrm{p}=0.04)$. Positive expression of c-erbB-2 in lymph node metastasis was correlated with lymph node involvement $(\mathrm{p}=0.04)$. Positive expression of $\mathrm{c}$-erbB-2 in the main mass of tumor and in lymph node metastasis was strongly correlated with postoperative survival $(p=0.00001 ; p=0.003$ respectively). We also found a relationship between EGF expression in gastric tumor and survival time $(p=0.003)$. No association was noted between the expression of EGFR in the main mass of tumor and in lymph node metastasis and between the expression of EGF in lymph node metastasis and survival time. Our results suggest that the expression of c-erbB-2 and EGF protein can help predict the postoperative survival time.
\end{abstract}

Key words: c-erbB-2, EGF, EGFR, gastric carcinoma

\section{Introduction}

Gastric carcinoma still remains one of the most common alimentary tract malignancies worldwide, although the last decade has brought a falling tendency in its incidence and mortality rate [1,2]. The process of carcinogenesis in the stomach involves a number of factors, including the family of epidermal growth factors. Growth factors have been found in both mature and embryonic tissues. These important regulators of

Correspondence: J. Czyżewska, Department of Clinical Laboratory Diagnostics, Medical University of Białystok, Waszyngtona 15a str, 15-274 Białystok, Poland; tel.: (+4885) 7485942, fax.: (+4885) 7485990, e-mail: czyzyk15@op.pl proliferation and differentiation play a significant role in the maintenance of epithelial integrity [3]. Physiologically, normal epithelial cells secrete growth factors which regulate cell exchange through autocrine and paracrine pathways. It is anticipated that these factors can regulate transition from $\mathrm{G} 2$ phase and mitosis of the cell cycle [4]. It has been demonstrated that ErbB1 (EGFR) and ErbB2 (c-erbB-2/HER-2) are associated with the development of many carcinomas. Increased ErbB1 expression has been observed in numerous types of carcinomas, including breast carcinoma, glioblastoma, gastric carcinoma and squamous cell carcinoma (SCC). In certain types of neoplasms, ErbB1 overexpression is accompanied by intercellular domain deletion that leads to constitutive activation. Moreover, ErbB1 activation via the autocrine pathway, 
attributed to the correlation with one or more EGFdependent ligands, may have a crucial role in neoplastic transformation $[5,6]$. In the case of breast carcinoma, gene c-erbB-2 amplification is a significant index of early relapse and shorter survival [7]. EGF plays an important part in the stimulation of epithelial proliferation, and in differentiation and growth of cells in the alimentary tract. It accelerates healing of ulcerative niches and ensures cytoprotection in the stomach. The EGF is produced in the submandibular salivary glands and in Brunner's glands in the duodenum. It is capable of binding to the specific receptor (EGFR) located in the cell membrane [8]. It has been shown that EGFR expression increases in gastric carcinoma tissues and correlates with unfavorable prognosis. EGF exerts an effect on the growth of carcinoma cells; however, its role in this process has not been fully elucidated [3].

The human proto-oncogene c-erbB-2 (HER-2) is a transmembrane glycoprotein showing structural homology with the epidermal growth factor receptor (EGFR). In physiological conditions, it affects cell growth and differentiation $[9,10]$. The c-erbB-2 expression correlates with the clinico-pathological stage of the disease and with its relapse in breast carcinoma [11], ovarian carcinoma [12] and lung carcinoma [13]. It has been revealed that the overexpression of gene c-erbB-2 and the gene-coded protein in gastric carcionma correlates with the intestinal-type carcinoma [14], lymph node metastases [15], peritoneal spread [16] and overall survival $[17,18]$.

The present study objective was to assess the expression of c-erbB-2, EGF and EGFR proteins in correlation with chosen clinico-pathological parameters and survival time in patients after curative resection of advanced gastric carcinoma.

\section{Material and methods}

Collection of samples. The study group consisted of 55 chosen patients with advanced gastric carcinoma (17 women and 38 men), operated on in the years 1996-98. The mean age was 60.4 years (range 30-78). The patients were clinically monitored for 84 months.

Immunohistochemistry. In all cases, specimens were obtained from the main mass of tumor and metastatic lymph nodes. They were fixed in $40 \mathrm{~g} / \mathrm{L}$ formaldehyde, embedded in paraffin and cut into $5 \mu \mathrm{m}$ sections. The sections were deparaffinized in three changes of xylene and hydrated through an alcohol series of a decreasing concentration. For detection of c-erbB-2 and EGF proteins, the sections were heated to $95^{\circ} \mathrm{C}$ for $15 \mathrm{~min}$ in citrate buffer $(10 \mathrm{mmol} / \mathrm{l})$ and incubated with $0.5 \%$ hydrogen peroxide solution in methanol for $15 \mathrm{~min}$ and with monoclonal antibodies c-erbB-2 (NCL-c-erbB-2-316, Novocastra, diluted 1:50) and EGF (clone EGF-10, Sigma Aldrich, Poland, diluted 1:50) for 1 hour. Novostain Super ABC Kit (NCL- ABCm, Novocastra Laboratories Ltd, UK) was applied as a detection kit. In order to detect EGFR protein expression, the pre-deparaffinized and hydrated sections were incubated with $3 \%$ hydrogen peroxide solution and then with polyclonal antibody EGFR (p-EGFR, sc:12351, Santa Cruz
Biotechnology, Inc, dilution 1:100) throughout the night at room temperature. LSAB+HRP Kit (DAKO) was used for detection. The antigen-antibody complex was visualized by means of DAB chromogen (S3000, DAKO, Poland). After rinsing in distilled water, the sections were stained with hematoxylin and eosin. After dehydration and mounting on a Canadian balsam, the sections were subjected to histopathological microscopic examination.

Evaluation of samples. Protein expression was assessed using a semi-quantitative method and defined as follows:

- High expression - when more than $50 \%$ of carcionoma cells were c-erbB-2, EGF and EGRF-positive

- Low expression- when there was no reaction or less than $50 \%$ of cells were c-erbB-2, EGF and EGFR-positive.

At least 500 carcinoma cells in each tissue specimen were microscopically found to be c-erbB-2, EGF and EGFR-positive $(\times 400)$.

Statistical analysis. Statistical analysis was based on test $\chi^{2}$ and exact Fisher's test. The $\mathrm{p}<0.05$ was considered statistically significant. Multivariate Cox regression analysis was done to evaluate the 5 -year overall survival.

\section{Results}

The study was performed on a group of 55 patients with advanced gastric carcinoma. The expression of tumor c-erbB-2 was observed by immunohistochemistry in the cell membrane, while EGF and EGFR in the cytoplasm (Fig. 1,2 and 3, respectively). Statistical analysis of the c-erbB-2, EGF and EGFR proteins revealed no association with patients' gender, tumor location in the main mass of tumor or lymph node metastasis. No correlation was also found between the expression of c-erbB-2 and EGF in the main mass of tumor and depth of invasion or histological differentiation as well as between EGR, EGRF and Bormann's classification in gastric tumor. Moreover, there was no association noted between c-erbB-2, EGF, EGFR expressions in lymph node metastasis and depth of invasion, Bormann's classification or Lauren's classification. We found no correlation between the expression of c-erbB-2, EGF in lymph node metastasis and histological differentiation. Similarly, there was no association found between the expression of EGF and EGFR in lymph node metastasis and age of patients or lymph node involvement (Table 1 and 2).

A strong, statistically significant correlation was found between the expression of c-erbB-2, EGF, EGFR in the main mass of tumor and lymph node metastasis $(p=0.000 ; p=0.000 ; p=0.00001$ respectively). Also an association was found between the expression of c-erbB-2 in gastric tumor and Lauren's classification $(\mathrm{p}=0.006)$. At the same time, correlation was observed between c-erbB-2 expression in the main mass of tumor and Bormann's classification or age of patients $(p=0.05$ and $p=0.03$ ). High EGFR expression in the main mass of tumor was associated with depth of invasion and histological differentiation $(\mathrm{p}=0.007$; $\mathrm{p}=0.04$ respectively). Borderline results were observed 
in the main mass of tumor between EGF expression and age $(\mathrm{p}=0.06)$ and between EGFR and Lauren's classification $(\mathrm{p}=0.08)$ (Table 1). Moreover, a strong correlation was found between c-erbB-2 expression in lymph node metastasis and lymph node presence $(\mathrm{p}=0.04)$ or age of patients $(\mathrm{p}=0.0002)$. Also, high expression of EGFR in lymph node metastasis was associated with histological differentiation $(\mathrm{p}=0.04)$ (Table 2).

Similarly, the expression of c-erbB-2 was found to correlate with positive tumor EGF and EGFR expressions $(\mathrm{p}=0.0004, \mathrm{p}=0.003$, respectively) (Tables 3,4$)$. Strong association was found between the expression of c-erbB-2 in the main mass of tumor and c-erbB-2 in lymph node metastasis $(\mathrm{p}=0.0002)$ (Table 5). Moreover, we found a correlation between the expression of EGF and EGFR in the main mass of tumor and lymph node metastasis $(p=0.0003 ; p=0.003$ respectively) (Table 7, 8). Positive staining for c-erbB-2 in lymph node metastasis was associated with EGFR expression in the main mass of gastric tumor $(\mathrm{p}=0.05)$ (Table 6).

As revealed by Cox's analysis, positive expression of c-erbB-2 in the main mass of tumor and in lymph node metastasis was strongly correlated with the overall postoperative survival time $(p=0.00001 ; p=0.003)$ (Figs. 4,7). The survival of patients with high tumor cerbB-2 expression was shorter (35 months) as compared to patients with low c-erbB-2 expression (84 months). Moreover, high mortality rate was observed in patients with high c-erbB-2 expression after 13-29 months, while in the low-c-erbB-2 expression group the mortality rate increased after 33 months and 46-60 months (Fig. 4). Also, we found a strong statistical correlation between c-erbB-2 expression in lymph node metastasis and time of survival ( $\mathrm{p}=0.003$ ) (Fig. 7). The overall survival in patients with high expression of cerbB-2 protein was 35 months, as compared to patients with low expression of c-erbB-2 - 68 months.

The mean survival time of patients with high tumor EGF expression was 84 months, as compared to patients with low expression -69 months. Increased mortality in the former group was observed between the 45-60 months after surgery. In the low-expression group, mortality increased after 11-23 months (Fig. 5), which was statistically significant $(\mathrm{p}=0.03$ ). There was no significant association between EGF expression in lymph node metastasis and time of survival (data not published).

In our study, the overall postoperative survival time in high-EGFR expression patients in the main mass of tumor was 84 months, as compared to low-EGFR expression patients (67 months) (Fig. 6). Similarly, patients with high EGFR expression in lymph node metastasis had a considerably longer postoperative survival time (61 months), compared to those with low-expression in metastasis (58 months) (data not published). However, no statistical significance was observed.

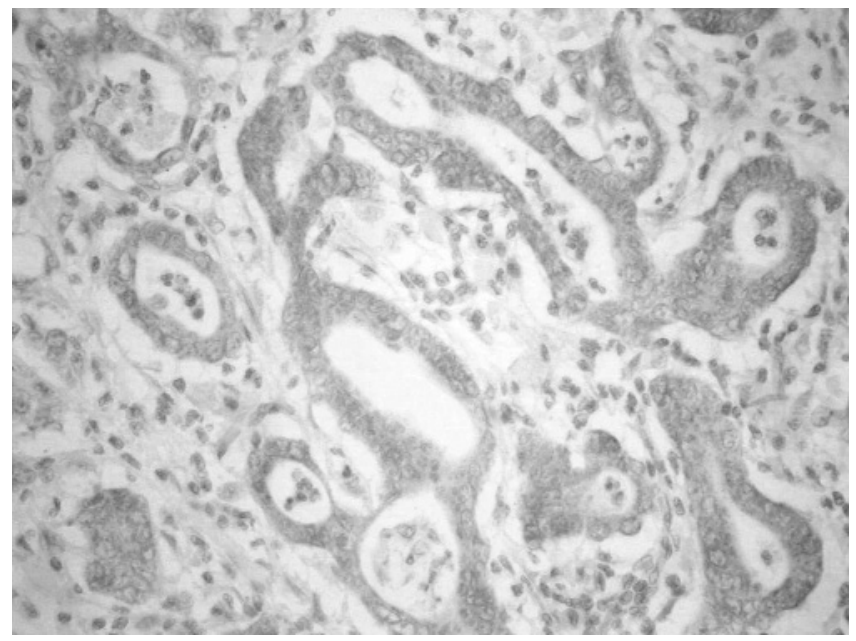

Fig. 1. Membrane cell staining pattern of c-erbB-2 in primary tumor.

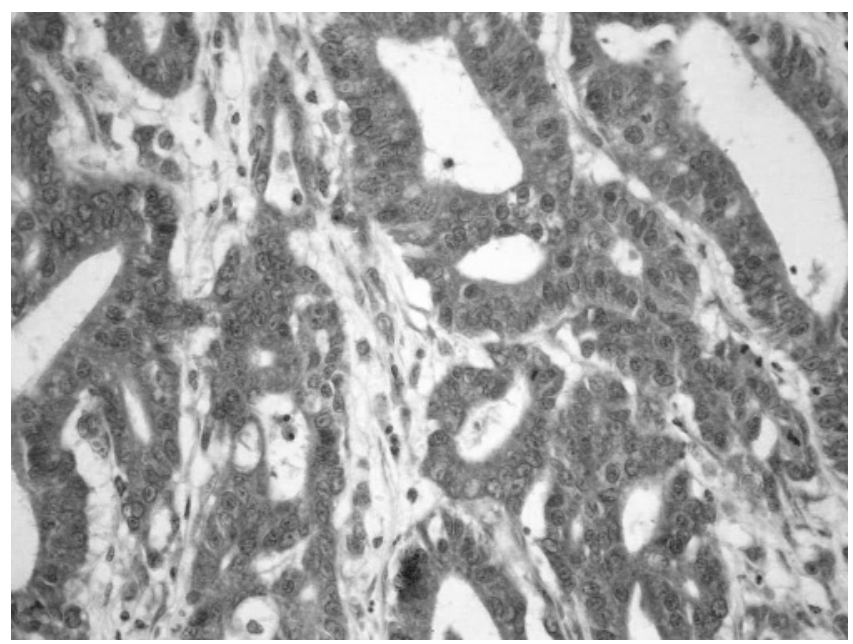

Fig. 2. Low expression of EGF in neoplastic cells.

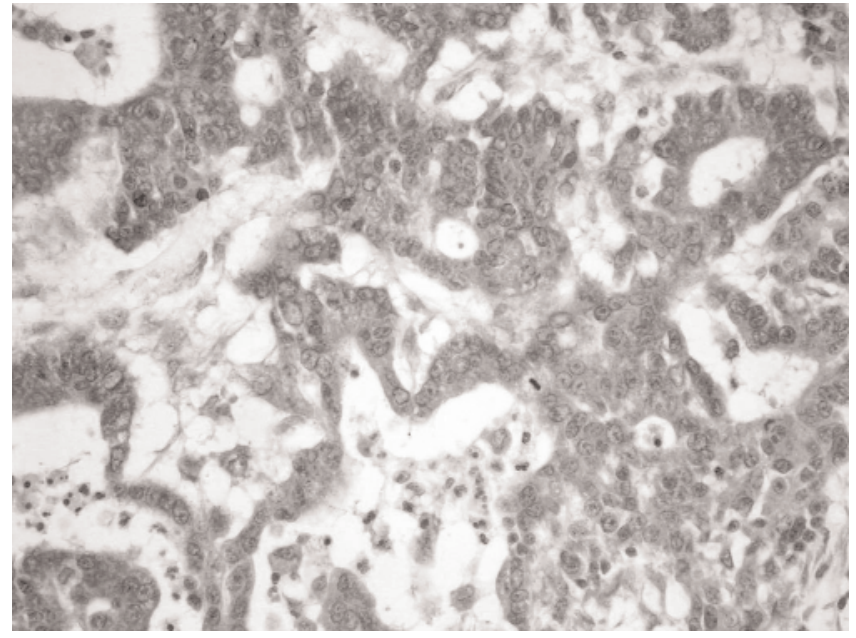

Fig. 3. High expression of EGFR in primary tumor. 
Table1. Expression of c-erbB-2, EGF, EGFR and chosen clinico-pathological parameters in gastric carcinoma.

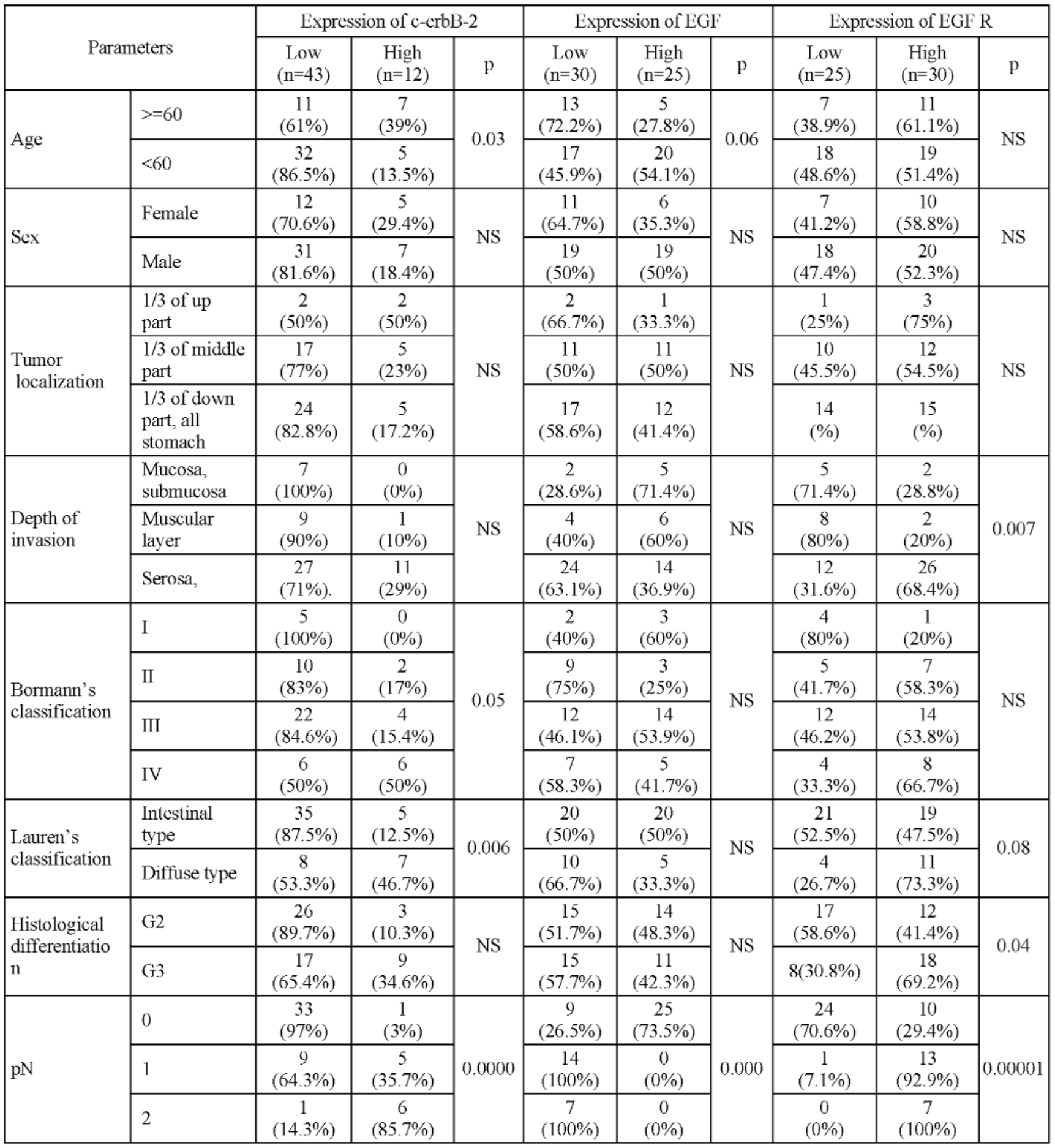

*NS - non statistical significence

\section{Discussion}

Growth factors constitute the cell transmission pathway, which plays a significant role in such processes as proliferation control, cell differentiation, apoptosis and neoplastic transformation $[19,20]$. The EGF family members exhibit a similar range of biological activ- ity induced by binding and activation of the EGF receptor [21]. Although the role of growth factors in oncogenesis of the alimentary tract diseases has been recently in the focus of attention, it is still not completely elucidated [22-24]. In the current study, a low immunohistochemical reaction to c-erbB-2 was observed in $78 \%$ of cases, mainly in the intestinal-type 
Table 2. Expression of c-erbB-2, EGF, EGFR in lymph node metastasis and histological differentiation.

\begin{tabular}{|c|c|c|c|c|c|c|c|c|c|c|}
\hline \multirow{2}{*}{\multicolumn{2}{|c|}{ Paramelers }} & \multicolumn{3}{|c|}{ Lxpression of c-crbb3-2 } & \multicolumn{3}{|c|}{ Lxpression of LGl } & \multicolumn{3}{|c|}{ Lxpression of LGi R } \\
\hline & & \multirow{2}{*}{$\begin{array}{c}\begin{array}{c}\text { Low } \\
(\mathrm{n}=21)\end{array} \\
7 \\
(70 \%)\end{array}$} & \multirow{2}{*}{$\begin{array}{c}\begin{array}{c}\text { Iligh } \\
(\mathrm{n}=7)\end{array} \\
3 \\
(30 \%)\end{array}$} & $\mathrm{p}$ & $\begin{array}{c}\text { Low } \\
(\mathrm{n}=13)\end{array}$ & $\begin{array}{l}\text { Iligh } \\
(\mathrm{n}=5)\end{array}$ & $\mathrm{p}$ & $\begin{array}{c}\text { Low } \\
(\mathrm{n}=11)\end{array}$ & $\begin{array}{l}\text { Iligh } \\
(\mathrm{t}=8)\end{array}$ & $\mathrm{p}$ \\
\hline \multirow{2}{*}{ Age } & $>=60$ & & & \multirow{2}{*}{0.0002} & $\begin{array}{c}6 \\
(85.7 \%)\end{array}$ & $\begin{array}{c}1 \\
(14.3 \%)\end{array}$ & \multirow{2}{*}{ NS } & $\begin{array}{c}5 \\
(62.5 \%)\end{array}$ & $\begin{array}{c}3 \\
(37.5 \%)\end{array}$ & \multirow{2}{*}{ NS } \\
\hline & $<60$ & $\begin{array}{c}14 \\
(77.8 \%)\end{array}$ & $\begin{array}{c}4 \\
(22.2 \%) \\
\end{array}$ & & $\begin{array}{c}7 \\
(63.6 \%) \\
\end{array}$ & $\begin{array}{c}4 \\
(36.4 \%)\end{array}$ & & $\begin{array}{c}6 \\
(54.5 \%) \\
\end{array}$ & $\begin{array}{c}5 \\
(45.5 \%) \\
\end{array}$ & \\
\hline \multirow{2}{*}{ Sex } & Female & $\begin{array}{c}8 \\
(72.7 \%)\end{array}$ & $\begin{array}{c}3 \\
(27.3 \%)\end{array}$ & \multirow{2}{*}{ NS } & $\begin{array}{c}6 \\
(85.7 \%)\end{array}$ & $\begin{array}{c}1 \\
(14.3 \%)\end{array}$ & \multirow{2}{*}{ NS } & $\begin{array}{c}6 \\
(75 \%)\end{array}$ & $\begin{array}{c}2 \\
(25 \%)\end{array}$ & \multirow{2}{*}{ NS } \\
\hline & Malc & $\begin{array}{c}13 \\
(76.5 \%)\end{array}$ & $\begin{array}{c}4 \\
(23.5 \%)\end{array}$ & & $\begin{array}{c}7 \\
(63.6 \%)\end{array}$ & $\begin{array}{c}4 \\
(36.4 \%)\end{array}$ & & $\begin{array}{c}5 \\
(45.5 \%)\end{array}$ & $\begin{array}{c}6 \\
(54.5 \%)\end{array}$ & \\
\hline \multirow{3}{*}{$\begin{array}{l}\text { Tumor } \\
\text { localization }\end{array}$} & $1 / 3$ of up part & $\begin{array}{c}\mathrm{l} \\
(50 \%)\end{array}$ & $\begin{array}{c}1 \\
(50 \%)\end{array}$ & \multirow{3}{*}{ NS } & $\begin{array}{c}2 \\
(100 \%)\end{array}$ & $\begin{array}{c}0 \\
(0 \%)\end{array}$ & \multirow{3}{*}{ NS } & $\begin{array}{c}2 \\
(100 \%)\end{array}$ & $\begin{array}{c}0 \\
(0 \%)\end{array}$ & \multirow{3}{*}{ NS } \\
\hline & $\begin{array}{l}1 / 3 \text { of middle } \\
\text { part }\end{array}$ & $\begin{array}{c}8 \\
(66.7 \%)\end{array}$ & $\begin{array}{c}4 \\
(33.3 \%)\end{array}$ & & $\begin{array}{c}5 \\
(71.4 \%)\end{array}$ & $\begin{array}{c}2 \\
(28.6 \%)\end{array}$ & & $\begin{array}{c}4 \\
(50 \%)\end{array}$ & $\begin{array}{c}4 \\
(50 \%)\end{array}$ & \\
\hline & $\begin{array}{l}1 / 3 \text { of down } \\
\text { part, all } \\
\text { stomach }\end{array}$ & $\begin{array}{c}12 \\
(85.7 \%)\end{array}$ & $\begin{array}{c}2 \\
(14.3 \%)\end{array}$ & & $\begin{array}{c}6 \\
(66.7 \%)\end{array}$ & $\begin{array}{c}3 \\
(33.3 \%)\end{array}$ & & $\begin{array}{c}6 \\
(60 \%)\end{array}$ & $\begin{array}{c}4 \\
(40 \%)\end{array}$ & \\
\hline \multirow{3}{*}{$\begin{array}{l}\text { Depth of } \\
\text { invasion }\end{array}$} & $\begin{array}{l}\text { Mucosa, } \\
\text { submucosa }\end{array}$ & $\begin{array}{c}4 \\
(100 \%) \\
\end{array}$ & $\begin{array}{c}0 \\
(0 \%) \\
\end{array}$ & \multirow{3}{*}{ NS } & $\begin{array}{c}0 \\
(0 \%) \\
\end{array}$ & $\begin{array}{c}0 \\
(0 \%) \\
\end{array}$ & \multirow{3}{*}{ NS } & $\begin{array}{c}0 \\
(0 \%) \\
\end{array}$ & $\begin{array}{c}0 \\
(0 \%) \\
\end{array}$ & \multirow{3}{*}{ NS } \\
\hline & $\begin{array}{l}\text { Muscular } \\
\text { layer }\end{array}$ & $\begin{array}{c}3 \\
(100 \%) \\
\end{array}$ & $\begin{array}{c}0 \\
(0 \%) \\
\end{array}$ & & $\begin{array}{c}1 \\
(100 \%)\end{array}$ & $\begin{array}{c}0 \\
(0 \%) \\
\end{array}$ & & $\begin{array}{c}1 \\
(100 \%) \\
\end{array}$ & $\begin{array}{c}0 \\
(0 \%) \\
\end{array}$ & \\
\hline & Serosa, & $\begin{array}{c}14 \\
(66.7 \%) \\
\end{array}$ & $\begin{array}{c}7 \\
(33.3 \%) \\
\end{array}$ & & $\begin{array}{c}12 \\
(70.6 \%)\end{array}$ & $\begin{array}{c}5 \\
(29.4 \%) \\
\end{array}$ & & $\begin{array}{c}10 \\
(55.6 \\
\end{array}$ & $\begin{array}{c}8 \\
(44.4) \\
\end{array}$ & \\
\hline \multirow{4}{*}{$\begin{array}{l}\text { Bormann's } \\
\text { classificatio } \\
n\end{array}$} & I & $\begin{array}{c}0 \\
(0 \%)\end{array}$ & $\begin{array}{c}0 \\
(0 \%) \\
\end{array}$ & \multirow{4}{*}{ NS } & $\begin{array}{c}0 \\
(0 \%) \\
\end{array}$ & $\begin{array}{c}0 \\
(0 \%) \\
\end{array}$ & \multirow{4}{*}{ NS } & $\begin{array}{c}0 \\
(0 \%) \\
\end{array}$ & $\begin{array}{c}0 \\
(0 \%) \\
\end{array}$ & \multirow{4}{*}{ NS } \\
\hline & II & $\begin{array}{c}6 \\
(85.7 \%) \\
\end{array}$ & $\begin{array}{c}1 \\
(14.3 \%) \\
\end{array}$ & & $\begin{array}{c}4 \\
(80 \%) \\
\end{array}$ & $\begin{array}{c}1 \\
(20 \%)\end{array}$ & & $\begin{array}{c}4 \\
(80 \%) \\
\end{array}$ & $\begin{array}{c}1 \\
(20 \%)\end{array}$ & \\
\hline & III & $\begin{array}{c}11 \\
(84.6 \%)\end{array}$ & $\begin{array}{c}2 \\
(15.4 \%) \\
\end{array}$ & & $\begin{array}{c}5 \\
(62.5 \%) \\
\end{array}$ & $\begin{array}{c}3 \\
(37.5 \%) \\
\end{array}$ & & $\begin{array}{c}4 \\
(50 \%) \\
\end{array}$ & $\begin{array}{c}4 \\
(50 \%) \\
\end{array}$ & \\
\hline & IV & $\begin{array}{c}4 \\
(50 \%) \\
\end{array}$ & $\begin{array}{c}4 \\
(50 \%) \\
\end{array}$ & & $\begin{array}{c}4 \\
(80 \%) \\
\end{array}$ & $\begin{array}{c}1 \\
(20 \%) \\
\end{array}$ & & $\begin{array}{c}3 \\
(50 \%) \\
\end{array}$ & $\begin{array}{c}3 \\
(50 \%) \\
\end{array}$ & \\
\hline \multirow{2}{*}{$\begin{array}{l}\text { Lauren's } \\
\text { classificatio } \\
\text { n }\end{array}$} & Intestinal type & $\begin{array}{c}13 \\
(81.3 \%)\end{array}$ & $\begin{array}{c}3 \\
(18.7 \%)\end{array}$ & \multirow{2}{*}{ NS } & $\begin{array}{c}9 \\
(69.2 \%)\end{array}$ & $\begin{array}{c}4 \\
(30.8 \%)\end{array}$ & \multirow{2}{*}{ NS } & $\begin{array}{c}7 \\
(53.8 \%)\end{array}$ & $\begin{array}{c}6 \\
(46.2 \%)\end{array}$ & \multirow{2}{*}{ NS } \\
\hline & Difluse type & $\begin{array}{c}8 \\
(66.7 \%)\end{array}$ & $\begin{array}{c}4 \\
(33.3 \%)\end{array}$ & & $\begin{array}{c}4 \\
(80 \%)\end{array}$ & $\begin{array}{c}1 \\
(20 \%)\end{array}$ & & $\begin{array}{c}4 \\
(66.7 \%)\end{array}$ & $\begin{array}{c}2 \\
(33.3 \%)\end{array}$ & \\
\hline \multirow{2}{*}{$\begin{array}{l}\text { Ilistological } \\
\text { differentiati } \\
\text { on }\end{array}$} & $\mathrm{G} 2$ & $\begin{array}{c}13 \\
(86.7 \%)\end{array}$ & $\begin{array}{c}2 \\
(13.3 \%)\end{array}$ & \multirow{2}{*}{ NS } & $\begin{array}{c}6 \\
(66.7 \%) \\
\end{array}$ & $\begin{array}{c}3 \\
(33.3 \%) \\
\end{array}$ & NS & $\begin{array}{c}3 \\
(33.3 \%) \\
\end{array}$ & $\begin{array}{c}6 \\
(66.7 \%) \\
\end{array}$ & 004 \\
\hline & G3 & $\begin{array}{c}8 \\
(66.7 \%) \\
\end{array}$ & $\begin{array}{c}5 \\
(33.3 \%) \\
\end{array}$ & & $\begin{array}{c}7 \\
(77.8 \%) \\
\end{array}$ & $\begin{array}{c}2 \\
(22.2 \%) \\
\end{array}$ & No & $\begin{array}{c}8 \\
(80 \%) \\
\end{array}$ & $\begin{array}{c}2 \\
(20 \%) \\
\end{array}$ & 0.04 \\
\hline & 0 & $\begin{array}{c}8 \\
(100 \%)\end{array}$ & $\begin{array}{c}0 \\
(0 \%)\end{array}$ & & $\begin{array}{c}0 \\
(0 \%)\end{array}$ & $\begin{array}{c}0 \\
(0 \%)\end{array}$ & & $\begin{array}{c}0 \\
(0 \%)\end{array}$ & $\begin{array}{c}0 \\
(0 \%)\end{array}$ & \\
\hline $\mathrm{pN}$ & 1 & $\begin{array}{c}10 \\
(76.9 \%) \\
\end{array}$ & $\begin{array}{c}3 \\
(23.1 \%) \\
\end{array}$ & 0.04 & $\begin{array}{c}8 \\
(72.7 \%) \\
\end{array}$ & $\begin{array}{c}3 \\
(27.3 \%) \\
\end{array}$ & NS & $\begin{array}{c}6 \\
(50 \%) \\
\end{array}$ & $\begin{array}{c}6 \\
(50 \%) \\
\end{array}$ & NS \\
\hline & 2 & $\begin{array}{c}3 \\
(42.9 \%)\end{array}$ & $\begin{array}{c}4 \\
(57.1 \%)\end{array}$ & & $\begin{array}{c}5 \\
(71.4 \%)\end{array}$ & $\begin{array}{c}2 \\
(28.6 \%)\end{array}$ & & $\begin{array}{c}5 \\
(71.4 \%)\end{array}$ & $\begin{array}{c}2 \\
(28.6 \%)\end{array}$ & \\
\hline
\end{tabular}

*NS - non statistical significence

carcinoma according to Lauren, but also in type II and IV according to Bormann's classification. There was no correlation of c-erbB-2, EGR, EGFR expression in gastric carcinoma with gender or location. There was also no association between the expression of c-erbB2, EGF in gastric tumor and depth of invasion or histological differentiation. Moreover, no correlation was observed between positive staining for EGF and EGFR in the main mass of tumor and Bormann's classification, which was in agreement with other authors $[25,26]$. Tsigris et al. [28] found no correlation between c-erbB-2 expression in gastric carcinoma and histological subtype, differentiation grade, tumor location, TNM stage, gastric wall invasion depth and pres- 
Table 3. Expression of c-erbB-2 and EGF in primary tumor of gastric carcinoma.

\begin{tabular}{|c|c|c|c|}
\hline \multirow{2}{*}{ EGF } & \multicolumn{3}{|c|}{ c-erbB-2 } \\
\cline { 2 - 3 } & $\begin{array}{c}\text { Low } \\
\text { expression } \\
(\mathrm{n}=43)\end{array}$ & $\begin{array}{c}\text { High } \\
\text { expression } \\
(\mathrm{n}=12)\end{array}$ & $\mathrm{p}$ \\
\hline Low expression & $18(60 \%)$ & $12(40 \%)$ & \multirow{2}{*}{0.0004} \\
\hline High expression & $25(100 \%)$ & $0(0 \%)$ & \\
\hline
\end{tabular}

Table 4. Expression of c-erbB-2 and EGFR in primary tumor of gastric carcinoma.

\begin{tabular}{|c|c|c|c|}
\hline \multirow{2}{*}{ LGil'R } & \multicolumn{3}{|c|}{ c-erbB-2 } \\
\cline { 2 - 3 } & $\begin{array}{c}\text { Low expression } \\
(\mathrm{n}=43)\end{array}$ & $\begin{array}{c}\text { High } \\
\text { expression } \\
(\mathrm{n}=12)\end{array}$ & $\mathrm{p}$ \\
\hline Low expression & $24(96 \%)$ & $1(4 \%)$ & \multirow{2}{*}{0.003} \\
\hline High expression & $19(63 \%)$ & $11(37 \%)$ & \\
\hline
\end{tabular}

ence of lymph node metastases or distant metastases. Also Yu et al. [29] observed no association between the expression of c-erbB-2 and age, gender or tumor differentiation grade in gastric carcinoma patients. However, according to Orita, c-erbB-2-positive tumors showed incidence of peritoneal dissemination, liver metastasis and lymph node involvement, in comparison with findings in the c-erbB-2 negative ones [27]. Motojima et al. [30] found a relationship between cerbB-2 expression and lymph node metastasis in welldifferentiated gastric adenocarcinomas. The c-erbB-2positive tumors metastasized much more frequently not only to the local lymph nodes but also to distant sites, as compared to the c-erbB-2 -negative tumors. The c-erbB-2 as a co-receptor for various stromal growth factors co-operates with ErbB1 (EGF-receptor) and neuroregulin receptors (ErbB-3 and ErbB-4). Showing low expression in normal mature cells, ErbB2 is overexpressed in $20-30 \%$ of carcinomas of the breast, stomach, lungs and prostate [31]. At the same time, Lee et al. [32] found an association between the expression of c-erbB-2 and gender, Bormann's type, histological type and Lauren's classification. They also observed a correlation of borderline significance between age of patients and expression of c-erbB-2.

Orita $\mathrm{H}$ et al. [27] elucidated prognostic significance of the expression of c-erbB-2 oncogene in gastric carcinoma patients. They found out that c-erbB2 expression was associated with considerably shorter postoperative survival time. In patients with positive and negative c-erbB-2 expression, a 5-year survival reached $29 \%$ and $47 \%$, respectively. Similar results have been reported by some other authors $[4$, $14,25]$. These data suggest that c-erbB-2 expression can be a prognostic factor for gastric carcinoma
Table 5. Expression of c-erbB-2 in main mass of tumor and lymph node metastasis.

\begin{tabular}{|l|c|c|c|}
\hline \multirow{2}{*}{$\begin{array}{c}\text { c-erbB-2 } \\
\text { (lymph node) }\end{array}$} & $\begin{array}{c}|c| \\
\text { Low } \\
\text { expression } \\
(\mathrm{n}=17)\end{array}$ & $\begin{array}{c}\text { High } \\
\text { expression } \\
(\mathrm{n}=11)\end{array}$ & $\mathrm{p}$ \\
\hline Low expression & $17(81 \%)$ & $4(19 \%)$ & \multirow{2}{*}{0.0002} \\
\hline High expression & $0(0 \%)$ & $7(100 \%)$ & \\
\hline
\end{tabular}

Table 6. Expression of c-erbB-2 in lymph node metastasis and EGFR in main mass of tumor.

\begin{tabular}{|c|c|c|c|}
\hline \multirow{2}{*}{ FGFR } & \multicolumn{3}{|c|}{ c-crbl-2 } \\
\cline { 2 - 3 } & $\begin{array}{c}\text { Low } \\
\text { expression } \\
(\mathrm{n}=21)\end{array}$ & $\begin{array}{c}\text { Iligh } \\
\text { expression } \\
(\mathrm{n}=7)\end{array}$ & $\mathrm{p}$ \\
\hline Low expression & $8(100 \%)$ & $0(0 \%)$ & \multirow{2}{*}{0.05} \\
\hline lligh expression & $13(65 \%)$ & $7(35 \%)$ & \\
\hline
\end{tabular}

Table 7. Expression of EGF and EGFR in main mass of tumor.

\begin{tabular}{|l|c|c|c|}
\hline \multirow{2}{*}{ LGIR } & \multicolumn{3}{|c|}{ FGF } \\
\cline { 2 - 4 } & $\begin{array}{c}\text { I.ow } \\
\text { expression } \\
(\mathrm{n}=30)\end{array}$ & $\begin{array}{c}\text { High } \\
\text { expression } \\
(\mathrm{n}=25)\end{array}$ & $\mathrm{p}$ \\
\hline Tow xpression & $7(28 \%)$ & $18(72 \%)$ & \multirow{2}{*}{0.0003} \\
\hline High expression & $23(76 \%)$ & $7(24 \%)$ & \\
\hline
\end{tabular}

Table 8. Expression of EGF and EGFR in lymph node metastasis.

\begin{tabular}{|c|c|c|c|}
\hline \multirow{2}{*}{ FGGF } & \multicolumn{3}{|c|}{ LGl } \\
\cline { 2 - 3 } & $\begin{array}{c}\text { Low } \\
\text { expression } \\
(\mathrm{n}=13)\end{array}$ & $\begin{array}{c}\text { Iligh } \\
\text { expression } \\
(\mathrm{n}=5)\end{array}$ & $\mathrm{p}$ \\
\hline Low expression & $10(91 \%)$ & $1(9 \%)$ & \multirow{2}{*}{0.03} \\
\hline Iligh expression & $3(43 \%)$ & $4(57 \%)$ & \\
\hline
\end{tabular}

patients. However, according to other studies, cerbB-2 does not exert a significant effect on the overall survival time in gastric carcinoma patients $[33,34]$. We observed a significant correlation between c-erbB-2 expression in the main mass of tumor and postoperative survival time of patients (Fig. 1). Patients with high tumor expression of this protein had a considerably shorter postoperative survival time, as compared to the low-expression patients. These results suggest that c-erbB-2 expression may function as a prognostic factor for patients with advanced gastric carcinoma.

EGF acts as a potential mitogen both for normal and neoplastic cells through interaction with a specific cell surface receptor. EGF binding leads to phosphorylation of tyrosine receptor residue, causing 


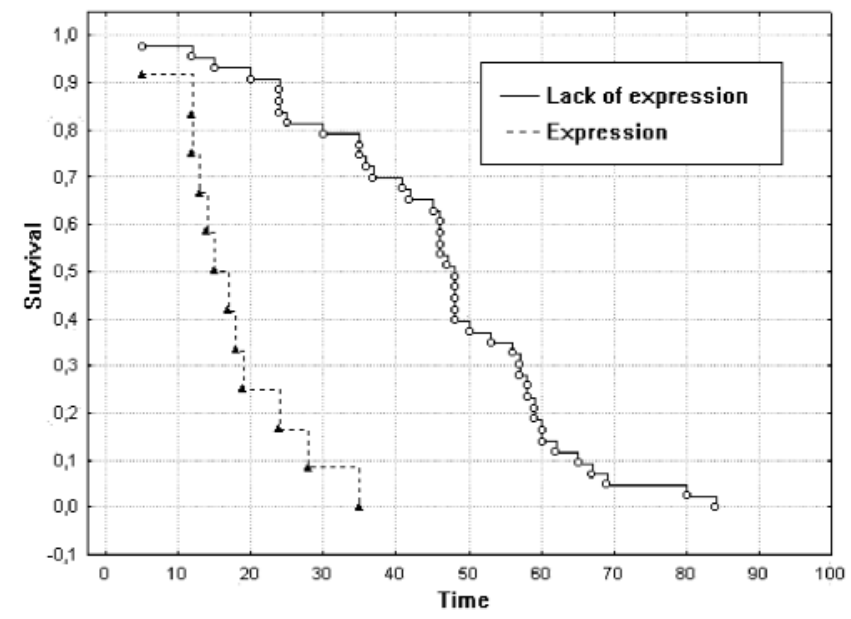

Fig. 4. Correlation of c-erbB-2 protein expression in main mass of tumor with survival of patients with advanced gastric cancer.

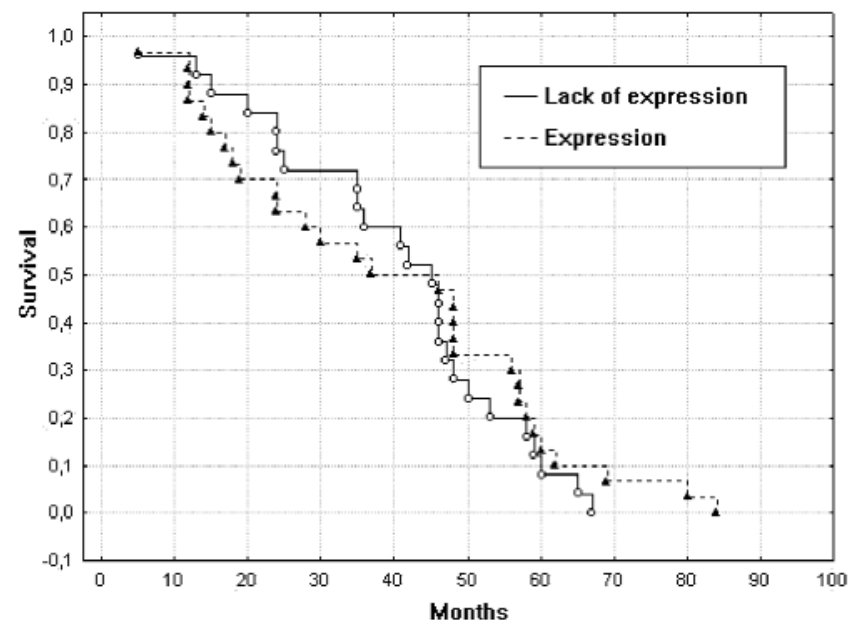

Fig. 6. Correlation of EGFR protein expression in main mass of tumor with survival of patients with advanced gastric cancer.

transduction of the intracellular signal and enhancement of several regulatory cascades associated with lithogenesis [35]. The expression of EGF receptor or EGF correlates with unfavorable prognosis in gastric carcinoma patients [37]. It has been demonstrated that patients who simultaneously had high expression of EGFR and TGF- $\alpha$ had much worse prognosis - a 5 -year survival time reached $12 \%$. At low concentration of these two proteins or when only the expression of EGFR or its ligand was observed, the 5-year survival increased up to $45 \%$ and $36 \%$, respectively [38]. In our study, the postoperative survival time in patients with high tumor EGF expression was longer (approximately 1 year), as compared to patients with low expression of this protein (Fig. 5). As reported by some authors, EGF expression in gastric carcinoma correlates with the depth of invasion in the gastric wall and with the presence of lymph node metastases, and indicates "worse" 5-year survival [39]. We found

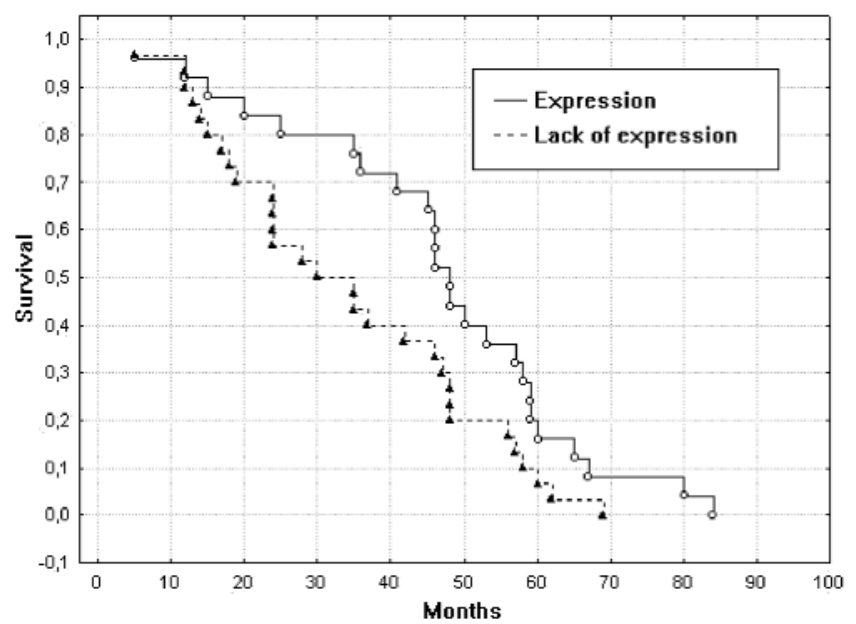

Fig. 5. Correlation of EGF protein expression in main mass of tumor with survival of patients with advanced gastric cancer.

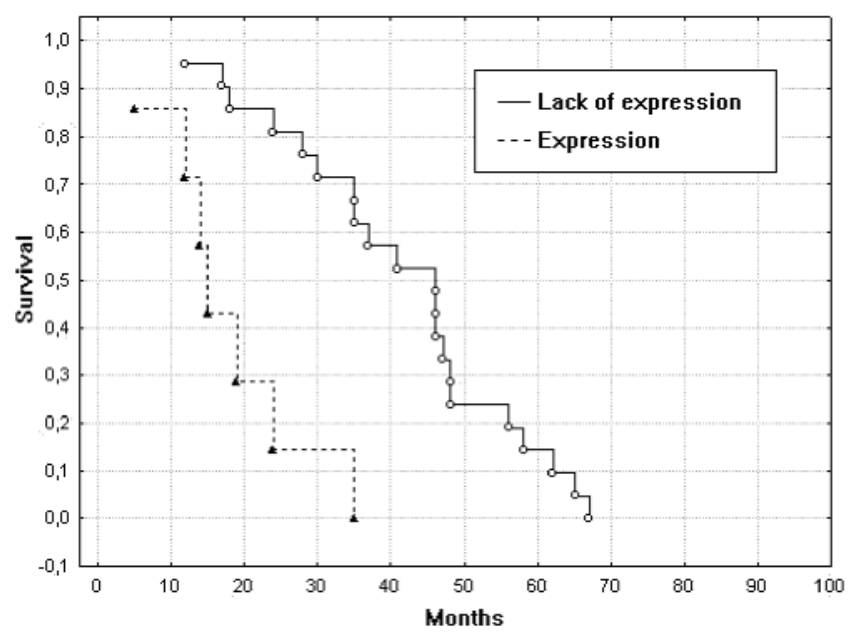

Fig. 7. Correlation of c-erbB-2 protein expression in lymph node metastasis with survival of patients with advanced gastric cancer.

that high expression of EGF in the main mass of tumor may predict longer time of postoperative survival. However, we revealed a strong, statistically significant relationship between EGF expression and lymph node involvement.

The first preliminary data concerning the level of EGFR in the gastric wall were described by Yasiu et al. [36], indicating an increase in the level of EGFR in neoplastic tissue compared to normal mucosa. Similar observations have been reported by other authors [40,41]. We also found much stronger immunohistochemical reaction in neoplastic tissue than in normal tissue (unpublished data). The increase in EGFR level was associated with clinical advancement of cancer and with shorter survival time. The elevated EGFR level was noted especially in more invasive carcinomas (T3/4), with lymph node involvement, in advanced carcinomas according to UICC (III), in low-differentiated cancers, in diffuse- 
type carcinomas according to Lauren and those located far from the cardia. Kopp et al. [40] suggested that in the case of chronic inflammation or tissue damage the physiological effect of the ligand for the EGF-receptor pathway, associated with the regulation of regeneration and healing in the gastric mucosa, may additionally stimulate the process of neoplastic transformation in this mucosa and tumor progression. We observed EGFR expression in more than $54 \%$ of gastric cancers. High expression was observed mainly in the intestinal type and poorly differentiated carcinomas, as well as in those infiltrating the whole gastric wall or at least into the serosa layer, the results being statistically significant. As reported by Gamboza-Dominguez et al. [43], lack or low expression of EGFR protein was significantly correlated with prolonged postoperative survival time, as compared to moderate and strong expression. In the current study, survival time in patients with high tumor EGFR expression was 17 months longer, as compared to those with low expression (Fig. 6). No correlations were observed between survival time and EGFR expression in metastatic lymph nodes ( 3 months; data not published). Thus, it can be assumed that EGFR expression in the main mass of tumor in patients with advanced gastric cancer may indicate a "better" 5 -year overall survival time. However, the results were statistically insignificant.

A significant correlation was observed between cerbB-2 and EGF, and EGFR expression in tumor. Also EGF expression in the main mass of tumor was associated with EGFR expression in gastric tumor and EGF expression in the metastatic lymph node strongly correlated with EGFR expression. Our results may indicate a relationship between EGF expression and histological malignancy in the main mass of tumor. The primary tumor c-erbB-2 expression was most strongly correlated with survival time, which was longer by 49 months in the high-expression group, compared to the group with negative expression. High expression of EGF protein was observed in moderately-differentiated tumors. Patients with high tumor EGF expression had longer survival time than those with low expression (statistically significant differences). High expression of EGFR protein was observed in types III and IV according to Bormann's classification. Postoperative survival time in patients with high EGFR expression both in the main tumor mass and in metastatic lymph nodes was considerably longer as compared to low expression (lack of statistical significance). Concluding, our results indicate the usefulness of the assessment of c-erbB-2 and EGF expression in relation to patients' survival.

\section{References}

[ 1] Howson CP, Hiyama T, Wynder EL. The decline in gastric cancer: epidemiology of an unplanned triumph. Epidemiol Rev.1986;8:1-27.
[2] La Vecchia C, Lucchini F, Negri E, Boyle P, Maisonneuve P, Levi F. Trends of cancer mortality in Europe, 1955-1989: I, Digestive sites. Eur J Cancer. 1992;28:132-235.

[3] Xia L, Yuan Y-Z, Xu Ch-D, Zhang Y-P, Qiao M-M, Xu J-X. Effects of epidermal growth factor on the growth of human gastric cancer cell and the implanted tumour of nude mice. World J Gastroenterol. 2002;8:455-458.

[ 4] Tsugawa K, Yonemura Y, Hirono Y, Fushida S, Kaji M, Miwa $\mathrm{K}$, Miyazaki I, Yamamoto H. Amplification of the c-met, cerbB-2 and epidermal growth factor receptor gene in human gastric cancers: correlation to clinical features. Oncology. 1998:55:475- 481.

[ 5] Salomon DS, Brandt R, Ciardiello F, Normanno N. Epidermal growth factor- related peptides and their receptors in human malignancies. Crit Rev Oncol Hematol. 1995;19:183-232.

[ 6] Medelsohn J, Baselga J. The EGF receptor family as targets for cancer therapy. Oncogene. 2000;19:6550- 6565.

[ 7] Berger MS, Locher GW, Saurer S, Gullick WJ, Waterfield MD, Groner B, Hynes NE. Correlation of c-erbB-2 gene amplification and protein in human breast carcinoma with nodal status and nuclear grading. Cancer Res. 1988;48:12381243.

[ 8] Playford RJ, Wright NA. Why is epidermal growth factor present in the gut lumen? Gut. 1996;38:303-305.

[9] Yamamoto T, Ikawa S, Akiyama T, Semba K, Nomura N, Miyajima N, Saito T, Toyoshima K. Similarity of protein encoded by the human c-erbB-2 gene to epidermal growth factor receptor. Nature. 1986;319:230-234.

[10] Press MF, Cordon- Cardo C, Slamon DJ. Expression of the HER-2/neu proto- oncogene in normal human adult and fetal tissues. Oncogene. 1990;5:953-962.

[11] Sugano K, Ushiama M, Fukutomi T, Tsuda H, Kitoh T, Ohkura $\mathrm{H}$. Combined measurement of the c-erbB-2 protein in breast cancer tissues and sera is useful as a sensitive tumor marker for monitoring tumor relapse. Int J Cancer. 2000;89: 329-336.

[12] Yazici H, Dolapcioglu K, Buyru F, Dalay N. Utility of c-erbB2 expression in tissue and sera of ovarian cancer patients. Cancer Invest. 2000;18:110-114.

[13] Osaki T, Mitsudomi T, Oyama T, Nakanishi R, Yasumoto K. Serum level and tissue expression of c-erbB-2 protein in lung adenocarcinoma. Chest. 1995; 108:157-162.

[14] Nakajima M, Sawada H, Yamada Y, Watanabe A, Tatsumi M, Yamashita J, Matsuda M, Sakaguchi T, Hirao T, Nakano H. The prognostic significance of amplification and overexpression of c-met and c-erbB-2 in human gastric carcinomas. Cancer. 1999;85:1894-1902.

[15] Orita H, Maehara Y, Emi Y, Kakeji Y, Baba H, Korenaga D, Sugimachi K. c-erbB-2 expression is predictive for lymphatic spread of clinical gastric carcinoma. Hepatogastroenterology. 1997;44:294-298.

[16] Wu MS, Shun CT, Sheu JC, Wang HP, Wang JT, Lee WJ, Chen CJ, Wang TH, Lin JT. Overexpression of mutant p53 and c-erbB-2 proteins and mutations of the $\mathrm{p} 15$ and $\mathrm{p} 16$ genes in human gastric carcinoma: with respect to histological subtypes and stages. $J$ Gastroenterol Hepatol. 1998;13:305-310.

[17] Shun CT, Wu MS, Lin JT, Chen SY, Wang HP, Lee WJ, Wang TH, Chuang SM. Relationship of p53 and c-erbB-2 expression to histological features, Helicobacter pylori infection and prognosis in gastric cancer. Hepatogastroenterology. 1997; 44:604-609.

[18] Allgayer H, Babic R, Gruetzner KU, Tarabichi A, Schildberg FW, Fiess MM. c-erbB-2 is of independent prognostic relevance in gastric cancer and is associated with the expression of tumor- associated protease systems. J Clin Oncol. 2000;18: 2201-2209.

[19] Wagner S, Beil W, Westermann J, Logan RP, Bock CT, Trautwein C, Bleck JS, Manns MP. Regulation of gastric 
epithelial cell growth by Helicobacter pylori: offdence for a major role of apoptosis. Gastroenterology. 1997;113:18361847.

[20] Messa C, Russo F, Pricci M, Di Leo A. Epidermal growth factor and 17beta- estradiol effects on proliferation of a human gastric cancer cell line (AGS). Scand J Gastroenterol. 2000; 35:753-758.

[21] Granelli P, Fichera G, Zennaro F, Siardi C, Ruberto F, Fregoni F, Appierto V, Buffa R, Ferrero S, Biunno I. Expression of the epidermal growth factor receptor gene in human intestinal metaplasia: a preliminary report. Scand J Gastroenterol. 1997;32:485-489.

[22] Becker KF, Keller G, Hoefler H. The use of molecular biology in diagnosis and prognosis of gastric cancer. Surg Oncol. 2000;9:5-11.

[23] Werner M, Becker KF, Keller G, Hofler H. Gastric adenocarcinoma: pathomorphology and molecular pathology. J Cander Res Clin Oncol. 2001;127:207-216.

[24] Masaki T, Hatanaka Y, Nishioka M, Tokuda M, Shiratori Y, Reginfo W, Omata M. Activation of epidermal growth factor receptor kinase in gastric carcinoma: a preliminary study. $\mathrm{Am}$ J Gastroenterol. 2000;95:2135-2136.

[25] Pinto-de-Sousa J, David L, Almeida R, Leit?o D, Preto JR, Seixas M, Pimenta A. c-erbB-2 expression is associated with tumor location and venous invasion and influences survival of patients with gastric carcinoma. Int J Surg Pathol. 2002;10: 247-256.

[26] Dursun A, Poyraz A, Celik B, Akyol G. Expression of c-erbB2 oncoprotein in gastric carcinoma: correlation with histopathologic characteristics and analysis of Ki-67. Pathol Oncol Res. 1999;5:104-106.

[27] Orita H, Maehara Y, Emi Y, Kakeji Y, Baba H, Korenaga D, Sugimachi K. c-erbB-2 expression is predictive for lymphatic spread of clinical gastric carcinoma. Hepato-Gastroenterology. 1997;44:294-298.

[28] Tsigris Ch, Karayiannakis AJ, Syrigos KN, Zbar A, Diamantis T, Kalahanis N, Alexiou D. Clinical significance of soluble c-erbB-2 levels in the serum and urine of patients with gastric cancer. Anticancer Research. 2002;22:3061-3065.

[29] Yu Ch, Xu S, Ni X, Ling Y, Zhang G, Zhu Ch, Liu X. Study on the relationship between P-glycoprotein (P-gp) and cerbB-2 expression in gastric carcinoma. Chinese-German $J$ Clin Oncol. 2007;6(3):P222-P224.

[30] Motojima K, Furui J, Kohara N, Izawa K, Kanematsu T, Shiku H. erbB-2 expression in well- differentiated adenocarcinoma of the stomach predicts shorter survival after curative resection. Surgery. 1994;115:349-54.

[31] Klapper LN, Waterman H, Sela M, Yarden Y. Tumor-inhibity antibodies to HER-2/ErbB-2 may act by recruiting c-Cbl and enhancing ubiquitination of HER-2. Cancer Res. 2000;60: 3384-3388.

[32] Lee KE, Lee HJ, Kim YH, Yu HJ, Yang HK, Kim WH, Lee KU, Choe KJ, Kim JP. Prognostic significance of p53, nm23,
PCNA and c-erbB-2 in gastric cancer. Jpn J Clin Oncol. 2003;33:173-179.

[33] Gurel S, Dolar E, Yerci O, Samli B, Ozturk H, Nak SG, Gulten M, Memik F. The relationship between c-erbB-2 oncogene expression and clinicopathological factors in gastric cancer. J Int Med Res. 1999;27:74-78.

[34] Polkowski W, van Sandick JW, Offerhaus GJ, ten Kate FJ, Mulder J, Obertop H, van Lanschot JJ. Prognostic value of Lauren classification and c-erbB-2 oncogene overexpression in adenocarcinoma of the esophagus and gastroesophageal junction. Ann Surg Oncol. 1999;6:290-297.

[35] Carpenter G. Receptor tyrosine kinase substrates: src homology domains and signal transduction. Fed AM Soc Exp Boli J. 1992;6:3283-3289.

[36] Yasui W, Sumiyoshi H, Hata J, Kameda T, Ochiai A, Ito H, Tahara E. Expression of epidermal growth factor in human gastric and colonic carcinomas. Cancer Res. 1988;48:137-141.

[37] Yasui W, Hata J, Yokozaki H, Nakatani H, Ochiai A, Ito H, Tahara E. Interaction between epidermal growth factor and its receptor in progression of human gastric carcinoma. Int $J$ Cancer. 1988;41:211-217.

[38] Nicholson RI, Gee JM, Harper ME. EGFR and cancer prognosis. Eur J Cancer. 2001;37:S9-S15.

[39] Tokunaga A, Onda M, Okuda T, Teramoto T, Fujita I, Mizutani T, Kiyama T, Yoshiyuki T, Niski K, Matsukura N. Clinical significence of epidermal growth factor (EGF), EGF receptor and c-erbB-2 in human gastric cancer. Cancer. 1995; 75:1418-1425.

[40] Kopp R, Ruge M, Rothbauer E, Cramer C, Kraemling HJ, Wiebeck B, Schildberg FW, Pfeiffer A. Impact of epidermal growth factor (EGF) radioreceptor analysis on long-term survival of gastric cancer patients. Anticancer Res. 2002;22: 1161-1167.

[41] Coyle WJ, Sedlack RE, Nemec R, Peterson R, Duntemann T, Murphy M, Lawson J. Eradication of Helicobacter pylori normalizes elevated mucosal levels of epidermal growth factor and its receptor. Am J Gastroenterol. 1999;94:2885-2889.

[42] Ghaderi A, Vasel M, Maleck-Hosseini SA, Gharesi-Fard B, Khodami M, Doroudchi M, Modjtahedi $\mathrm{H}$. The expression of c-erbB-1 and c-erbB-2 in Iranian patients with gastric carcinoma. Pathol Oncol Res. 2002;8:252-256.

[43] Gamboza-Dominguez A, Dominguez- Fonseca C, Quintanilla- Martinez L, Reyes- Gutierrez E, Green D, Angles- Angles A, Busch R, Hermannstadter C, Nahrig J, Becker KF, Becker I, Hofler H, Fend F, Luber B. Epidermal growth factor receptor expression correlates with poor survival in gastric adenocarcinoma from Mexican patients: a multivariate analysis using a standardized immunohistochemical detection system. Mod Pathol. 2004;17:579-87.

Submitted: 22 February, 2009 Accepted after reviews: 16 July, 2009 